\title{
Variations in Old-Growth Structure and Definitions: Forest Dynamics on Wachusett Mountain, Massachusetts
}

\section{Citation}

Orwig, David A., Charles V. Cogbill, David R. Foster, and John F. O'Keefe. 2001. Variations in OldGrowth Structure and Definitions: Forest Dynamics on Wachusett Mountain, Massachusetts. Ecological Applications 11, no. 2: 437. doi:10.2307/3060900.

\section{Published Version}

doi:http:10.2307/3060900

\section{Permanent link}

http://nrs.harvard.edu/urn-3:HUL.InstRepos:30666656

\section{Terms of Use}

This article was downloaded from Harvard University's DASH repository, and is made available under the terms and conditions applicable to Other Posted Material, as set forth at http:// nrs.harvard.edu/urn-3:HUL.InstRepos:dash.current.terms-of-use\#LAA

\section{Share Your Story}

The Harvard community has made this article openly available.

Please share how this access benefits you. Submit a story.

\section{Accessibility}




\title{
VARIATIONS IN OLD-GROWTH STRUCTURE AND DEFINITIONS: FOREST DYNAMICS ON WACHUSETT MOUNTAIN, MASSACHUSETTS
}

\author{
David A. Orwig, ${ }^{1,3}$ Charles V. Cogbill,${ }^{2}$ David R. Foster, ${ }^{1}$ And John F. O'Keefe ${ }^{1}$ \\ ${ }^{1}$ Harvard University, Harvard Forest, P.O. Box 68, Petersham, Massachusetts 01366 USA \\ ${ }^{2}$ Plainfield, Vermont 05667 USA
}

\begin{abstract}
One of the largest old-growth forests in southern New England was recently "discovered" on the exposed upper slopes of Wachusett Mountain, Massachusetts, a heavily used recreational area located $<80 \mathrm{~km}(<50$ miles) from Boston. We analyzed historical records, dendroecological data, vegetation, and coarse woody debris to characterize the dynamics and development of four major old-growth stands on the mountain and explored the potential factors enabling these forests to survive and elude recognition as old-growth forests for $>150 \mathrm{yr}$. Historical data suggest that most of the area's forests were composed of a mixture of Quercus rubra and northern hardwood species. Species abundances and recruitment dynamics in the four stands exhibit highly variable spatial and temporal patterns across sites that differ in aspect and exposure. Three uneven-aged hardwood stands contain Quercus rubra in the largest size classes, various amounts of Fagus grandifolia, Acer, and Betula species in the middle size classes, and dense thickets of several shrub species in the small size classes. Several of a set of randomly aged individuals of $Q$. rubra, B. lenta, and $B$. alleghaniensis are at or very near the maximum longevity known for these species. A Tsuga canadensis stand contains unimodal size and age distributions, with trees $<60$ $\mathrm{cm}$ dbh and 100-300 yr old. Quercus rubra recruitment occurred on all sites from the 1600 s through the early 1800 s, when it dropped precipitously on most sites and was replaced by either Tsuga or Acer and Betula species. These recruitment changes were apparently driven by changes in disturbance regime over the last two centuries, from fire in the early record to hurricanes (1815 and 1938), and more recently, frequent wind, ice, and snow damage but no fire. Asynchronous tree-ring releases and suppression and relatively low amounts of coarse woody debris corroborate this interpretation. Chronic canopy damage produced short-statured and unusually gnarled trees, which gave the forest unusual resistance to severe winds from hurricanes, discouraged logging, and prevented the recognition of the forest's old-growth status despite its heavy recreational use.
\end{abstract}

Key words: coarse woody debris; disturbance; fire; forest history; ice damage; Massachusetts, USA; old-growth forests; recruitment dynamics; tree rings; Wachusett Mountain.

\section{INTRODUCTION}

Scientists, land managers, and policy makers have developed a recent awareness of the value of oldgrowth forest ecosystems as plant and animal habitat, repositories of genetic information, and sources of insights into dynamics and function of natural systems to help guide management decisions in second-growth forests (Foster et al. 1996a). This awareness has stimulated a widespread attempt to locate and characterize old-growth stands, which in turn has led to recognition of a much wider range of old-growth ecosystems than the stereotypic majestic forest comprised of immense, ancient trees (cf. Davis 1996). Historically, eastern North American ecologists have been pre-occupied with old-growth stands dominated by tall and immense shade-tolerant Tsuga canadensis (eastern hemlock) and other late successional species or Pinus (pine) (Nichols 1913, Lutz 1930, Fisher 1933, Cline and Spurr 1942,

Manuscript received 27 March 1999; revised 16 February 2000; accepted 28 February 2000.

${ }^{3}$ E-mail: orwig@fas.harvard.edu
Hough and Forbes 1943). Many of these stands are located on moist lower slopes, in deep valleys or ravines where they are sheltered from disturbance from wind and fire (Dunwiddie et al. 1996). Such site conditions, together with the structure and composition of the vegetation, generate a classic image of large statured trees in majestic and shady old-growth forest ecosystems.

In Massachusetts many of the early descriptions and reconstructions of virgin forests conformed to this stereotype. Recent inventories based on such a model of old-growth forests yielded a total of 28 stands comprising $\sim 230$ ha, most of which are dominated by large conifers occupying steep ravines and narrow valleys. All of these stands are located in remote, very hilly, and relatively inaccessible locations in the Berkshire Hills of western Massachusetts (Dunwiddie and Leverett 1996, Dunwiddie et al. 1996). Consequently, the discovery in 1995 of one the largest areas of old growth in southern New England on a mountainside near Boston by local environmentalists opposed to ski area expansion was remarkable. Unlike sites in western Mas- 
sachusetts, preliminary investigations confirmed these forests are dominated by northern hardwood species, occupy a 125-150 m elevational band on exposed, upper slopes of an isolated mountain, and occur in densely populated eastern Massachusetts $<65 \mathrm{~km}$ from the state's largest cities, Boston and Worcester (Cogbill 1995; P. Dunwiddie, personal communication). Even more surprising is the specific location, Wachusett Mountain, a State Reservation that is one of the busiest recreation areas in southern New England. More than 700000 people travel through the old-growth forest annually on numerous hiking and downhill skiing trails, and via an automobile road to the summit (Massachusetts Department of Environmental Management 1999). The forest has been actively used for recreation and increasingly dissected by trails since the early 19 th century and yet its old-growth status went unrecognized as recreationists, scientists, and state forest managers failed to appreciate the extremely ancient age of the dominant trees. The floristic composition, site conditions, and the relatively short and chronically damaged crown characteristics of the trees did not fit the established old-growth stereotype.

Discovery of this forest provides an important opportunity to examine the history, dynamics, structure, and composition of an old-growth ecosystem that is strikingly different from those described by earlier ecologists and foresters. In particular, we are interested in: (1) examining the old-growth attributes of the forest and its major environmental and vegetational characteristics; (2) characterizing the natural disturbance processes and site conditions in relationship to the unusual structure and composition of the forest; (3) exploring the factors that enabled the survival of trees over a $>300$-yr period in a region of intensive and widespread land use (O'Keefe and Foster 1998) and on slopes that are directly exposed to the infrequent but extremely destructive hurricanes and other windstorms that have affected the southern New England landscape (cf. Foster 1988, Boose et al. 2001); (4) investigating and interpreting the age-structure and growth history of the trees in light of these conditions and history; and (5) comparing the stand dynamics and growth responses of trees in four separate and very different stands that are similar in elevation but differ in aspect and exposure. Because the forest is located in a State Reservation, it faces ongoing threats from recreational development, road and infrastructure improvement, and visitation by old-growth enthusiasts. Thus, a final objective is to develop an initial scientific background for management decisions and further ecological study.

\section{Study Site}

Wachusett Mountain is located in the towns of Princeton and Westminster, Worcester County, in north central Massachusetts $\left(42^{\circ} 29^{\prime} \mathrm{N}, 71^{\circ} 53^{\prime} \mathrm{W}\right)$ and lies within the Worcester-Monadnock Plateau subregion of the northeastern highlands of Massachusetts (Griffith et al. 1994). Extending from 320 to $611 \mathrm{~m}$ above sea level (a.s.1.), this monadnock is the highest peak in Massachusetts east of the Connecticut River and is formed from a sill of Wachusett granodiorite, an erosion-resistant rock that has steep talus (boulder field) slopes produced by postglacial frost cracking (Robinson and Tucker 1992, Cogbill 1995). Soils on the higher elevation slopes where the old-growth stands occur are classified as Lyman-Tunbridge-Berkshire association, gently sloping to very steep, shallow and somewhat excessively drained with abundant rock outcrops (USDA 1996). Lower elevation slopes are less steep and support Berkshire-Marlow soils, which are very deep, well-drained fine sandy loams (USDA 1996). The regional vegetation is transition hardwoods, white pine, and hemlock (Westveld et al. 1956). The geology and elevation of the mountain provide a set of conditions (e.g., northern climate, talus slopes, shallow, acid soils, and long steep slopes) that is uncommon east of the Berkshires or south of the mountains of New Hampshire (Cogbill 1995).

North central Massachusetts has a humid continental climate, with prevailing westerly winds. Mean January temperature is $-4.4^{\circ} \mathrm{C}$, mean July temperature is $21.0^{\circ} \mathrm{C}$, and mean annual precipitation is $112 \mathrm{~cm}$, with $\sim 180 \mathrm{~cm}$ of snow (Massachusetts Department of Environmental Management 1979). The upper elevations of the mountain are particularly vulnerable to winter storms; ice deposition (i.e., rime and glaze) occurs frequently in the band of forest between 450 and $600 \mathrm{~m}$ a.s.l. and often causes substantial tree damage (Massachusetts Department of Environmental Management 1985).

The region immediately surrounding the mountain was an important center of Native American activity and habitation. "Wachusett" means "By the Great Hill" in Algonquin, and as late as the early 17th century a Nipmuck Indian village was located at the base of the mountain on the shores of Wachusett Lake (Massachusetts Department of Environmental Management 1985, Sinclair 1996). From 1791 to 1896 the Roper family farmed the north slope of Wachusett Mountain and had pastures and woodlots extending up to the toe of the steep slopes. A stone house was built on the summit in 1870 and became a tourist destination for summer boarders (Blake 1915). By the early 1890s, most of the remaining shrubs on the summit were removed during the construction of a three-story hotel, outbuildings, and roads to the summit (Blake 1915).

In 1899, Massachusetts bought the 560-ha area encompassing the summit and created the Wachusett Mountain State Reservation (WMSR; Massachusetts Department of Environmental Management 1985). The first ski trails were cut on the northern slopes in the 1920s and 1930s and the first ski lifts were installed in 1962. Major ski area expansions occurred in 1982 and 1983 when a lift to the summit and additional ski trails 30 to $60 \mathrm{~m}$ wide were cut and cleared through 
the old-growth forest (Massachusetts Department of Environmental Management 1985). The mountain is one of the most visited state forests in Massachusetts and has received increasing use by hikers and tourists travelling the many trails and summit roads. The summit is located in the center of the 817-ha Reservation, which is managed by the Massachusetts DEM. A 182ha area on the northern slope of the mountain that includes much of the old-growth forest is leased to a downhill skiing resort.

\section{Methods}

\section{Historical vegetation patterns}

Vegetation data on or in the vicinity of the mountain at the time of European settlement $(\sim 1760)$ were derived from lotting surveys that documented witness trees at the corners of land parcels of the original proprietors (Whitney 1994, Cogbill 1995). Early travelers to the mountain, including Peter Whitney (1793) and Henry D. Thoreau $(1843,1854)$, recorded detailed early postsettlement $(\sim 1790-1850)$ descriptions. Contemporary town land maps from the period of the height of agricultural development in the state (Massachusetts Archives 1830) indicate cultural features and vegetation including meadows, swamps, and woodland. In addition, land records (Worcester County Registry of Deeds, Worcester, Massachusetts, USA), written histories of Princeton (Hanaford 1852, Blake 1915), and historical photographs from the late 1800 s provide details of early settlement patterns and land use on the mountain during the early tourism period (Kingsley and Knab 1895).

\section{Modern composition}

An initial reconnaissance of the mountain that included limited tree coring confirmed the existence of a large, nearly contiguous zone of old-growth forest with gnarled, tapering tree boles on the mid- to upper slopes above the Roper Farm and located primarily in the town of Princeton (Foster et al. 1996b; Fig. 1). Within this zone we observed four distinct forest cover types and during the summers of 1996 and 1997, four separate old-growth stands were studied intensively (Fig. 1). Areas were selected based on preliminary ages obtained earlier and distinctive species composition that varied with topographic aspect, site, and morphological characteristics. In each area, we determined the age, structure, and composition of the overstory vegetation and sampled the sapling-layer vegetation. Vegetation was sampled in five $20 \times 20 \mathrm{~m}$ permanently marked plots established along transects oriented through the central portion of each area. Slope, aspect, topographic position, and the species and diameter at breast height (dbh) for every tree (stems $\geq 1.37 \mathrm{~m}$ tall and $\geq 8 \mathrm{~cm}$ dbh) were recorded in each plot. In each area, a relative importance value was calculated for each species by averaging relative density and relative basal area data from the five plots. In addition, tree heights of four dominant or codominant trees were obtained in each stand with a clinometer. All saplings (stems $>1.37 \mathrm{~m}$ tall and $<8 \mathrm{~cm} \mathrm{dbh}$ ) were counted by species within each plot. Nomenclature follows Gleason and Cronquist (1991).

In each plot, two to four trees were randomly selected and cored with an increment borer at $1.37 \mathrm{~m}$ height for radial growth analysis and age determinations. Additional cores from very old trees located outside of plots were obtained to reconstruct long-term dynamics. Cores were air dried, mounted, sanded, and aged with a dissecting microscope. For cores that missed the pith we added a few years (based on the early ring curvature and growth rate) to estimate total breast-height age. Ring widths were measured to the nearest $0.01 \mathrm{~mm}$ with a Velmex (East Bloomfield, New York, USA) measuring system. Cores were examined to derive periods of suppression and release based on criteria established by Lorimer and Frelich (1989), who defined a "major sustained release" as an average growth increase $\geq 100 \%$ lasting at least $15 \mathrm{yr}$ relative to the previous $15 \mathrm{yr}$ and a "moderate temporary release" as an average growth increase $\geq 50 \%$ lasting $10-15$ yr relative to the previous 10-15 yr. In addition, "abrupt growth decreases" of $\geq 25 \%$ sustained for at least 10 consecutive years relative to the previous $10 \mathrm{yr}$ were tallied to indicate canopy damage (cf. Foster 1988). These criteria, coupled with tree breast-height recruitment dates (age cohorts), were used to differentiate disturbance events from short-lived responses attributed to climatic factors (Lorimer and Frelich 1989, Nowacki and Abrams 1997).

\section{Coarse woody debris (CWD)}

All branch fragments or downed trees $\geq 10 \mathrm{~cm} \mathrm{dbh}$ rooted or formerly rooted in each plot were identified by species when possible by examination of wood pieces under a dissecting microscope, or as hardwood vs. conifer. Orientation and origin (uproot, bole snap, or unknown event) of each piece of debris were also determined. CWD volume was estimated by treating each log or branch segment as a cylinder, using length measurements and an average of end radii. The species and dbh were also recorded for all standing dead trees $\geq 8$ $\mathrm{cm}$ dbh.

\section{Results \\ Vegetation history}

The original forest that covered Wachusett Mountain supported the species found there today. Witness trees identified in lotting surveys prior to 1755 indicate that the vegetation consisted primarily of a mixture of Tsu$g a$ and northern hardwood species such as Acer (maple) and Fagus grandifolia (American beech) in Westminster and Quercus (oak) and Pinus (pine) with lesser amounts of Acer and Fagus in Princeton (Table 1). 


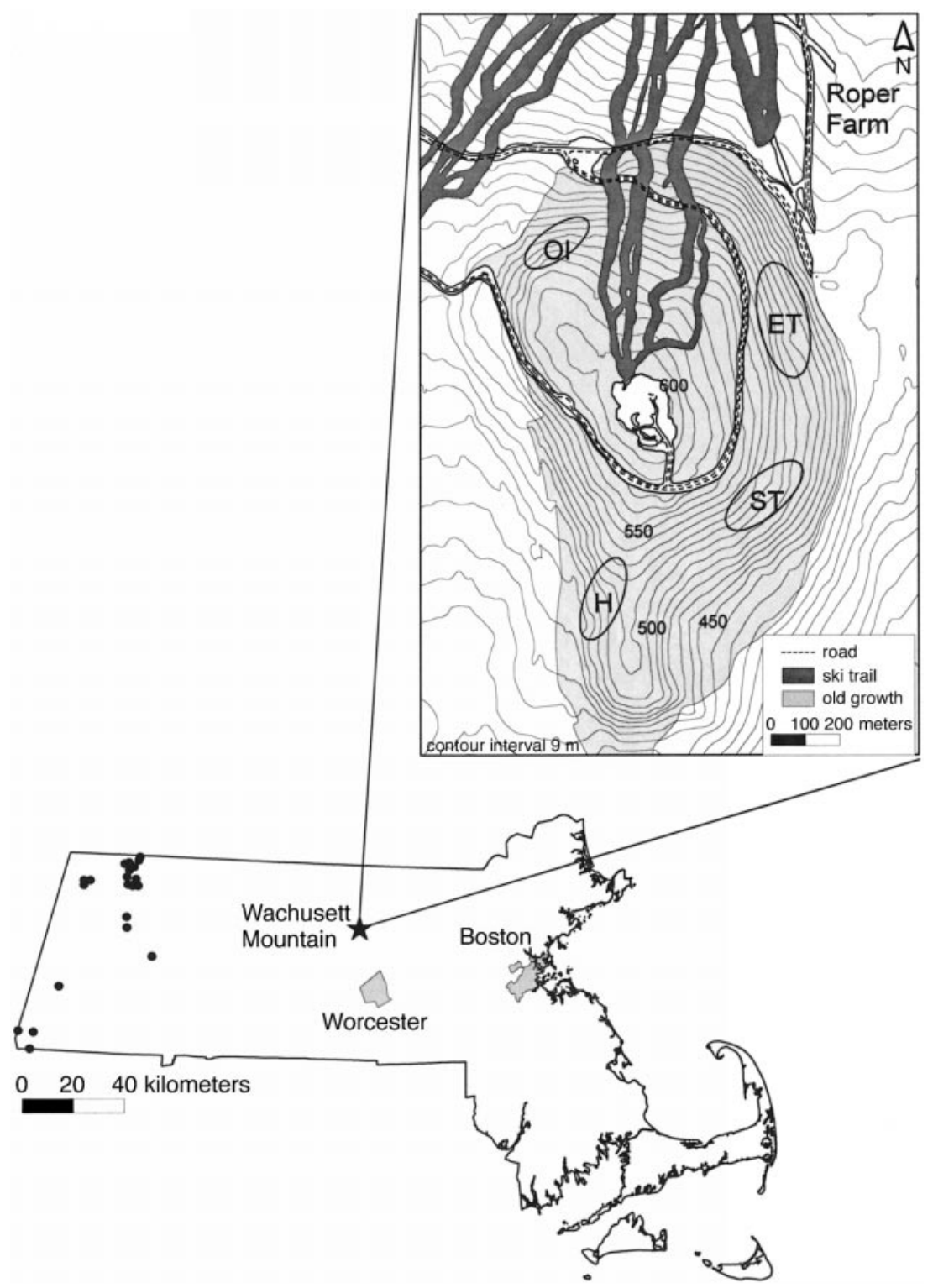

FIG. 1. Location of Wachusett Mountain in relation to the two largest cities and the other currently recognized old-growth sites in Massachusetts (solid circles; adapted from Dunwiddie and Leverett 1996). The inset shows the approximate extent of the old-growth area (shaded) on Wachusett Mountain (cf. Foster et al. 1996b), the general location of the Old Indian (OI), Eastern Talus (ET), Southern Talus (ST), and Hemlock (H) areas, and the 19th Century location of the Roper Farm. Ski trails are shown as dark bands spreading down and out from the summit.

Land on the lower slopes of the mountain was not settled until 1790 and the earliest description of vegetation on Wachusett Mountain followed shortly, when Peter Whitney (1793) characterized the upper 40 ha as supporting low, small trees with flat tops growing on very steep, broken, and ledgy sites. He observed progressively larger trees on lower slopes and mentioned that the lower and flatter 120 ha would make "considerable pasture land." In contrast, the summit was described as containing flat rock and ledges of rocks, with abundant blueberry bushes on areas with sufficient soil (Whitney 1793). Fifty years later, Thoreau (1843) made similar observations as he walked up the mountain, describing "denser forest, which gradually became dwarfed till there were no trees whatever upon the mountain crest."

Tree composition on the lower northern slope of the mountain (Roper Farm), as reconstructed from witness trees during the early to mid-1800s, consisted primarily of Quercus rubra (northern red oak), Castanea, Fagus, and Fraxinus americana (white ash; Table 1). By this time, these forested upper slopes contrasted sharply with the surrounding landscape. In 1830, $>95 \%$ of Princeton (8916 ha) was open agricultural land; the 
TABLE 1. Percentage of witness trees in early records from Wachusett Mountain.

\begin{tabular}{|c|c|c|c|}
\hline Species & $\begin{array}{c}\text { Princeton } \\
1734-1738 \\
(n=127)\end{array}$ & $\begin{array}{c}\text { Westminster } \\
1736-1755 \\
(n=245)\end{array}$ & $\begin{array}{c}\text { Roper Farm } \\
1790-1869 \\
(n=17)\end{array}$ \\
\hline Quercus spp. & 3.2 & 1.6 & . \\
\hline Q. rubra & 2.4 & 6.1 & 35.3 \\
\hline$\widetilde{Q} \cdot a l b a$ & 10.2 & $\ldots$ & $\ldots$ \\
\hline Q. velutina & 6.3 & $\ldots$ & $\ldots$ \\
\hline Pinus spp. & 7.9 & 2.0 & $\ldots$ \\
\hline P. strobus & 14.2 & 3.7 & $\ldots$ \\
\hline$P$. rigida & 7.9 & 1.6 & $\ldots$ \\
\hline Castanea dentata & 3.1 & 9.0 & 17.6 \\
\hline Carya spp. & 0.8 & $\ldots$ & 5.9 \\
\hline Acer spp. & 9.4 & 11.0 & 5.9 \\
\hline Acer negundo & & 1.6 & \\
\hline Fagus grandifolia & 7.1 & 19.2 & 17.6 \\
\hline Betula spp. & 0.8 & 3.3 & $\ldots$ \\
\hline B. lenta & 2.4 & 2.9 & $\ldots$ \\
\hline B. papyrifera & 0.8 & & $\ldots$ \\
\hline Tsuga canadensis & 7.1 & 23.7 & $\ldots$ \\
\hline Fraxinus spp. & 5.5 & 5.3 & \\
\hline F. americana & 2.4 & 0.8 & 17.6 \\
\hline Populus spp. & 4.7 & 2.4 & $\ldots$ \\
\hline Ostrya virginiana & $\ldots$ & 0.4 & $\ldots$ \\
\hline Ulmus spp. & 0.8 & 0.4 & $\ldots$ \\
\hline Prunus spp. & 2.4 & $\ldots$ & $\ldots$ \\
\hline Picea spp. & 0.8 & 4.5 & $\ldots$ \\
\hline Juniperus spp. & $\ldots$ & 0.4 & $\ldots$ \\
\hline
\end{tabular}

Notes: Records are from presettlement lotting surveys in Princeton and Westminster, Massachusetts, and in land survey boundaries in early deeds from the Roper Farm, located on the northern slope of Wachusett Mountain (data from Proprietor Records of Rutland, Proprietor Records of Westminster, and deeds from Worcester County Registry of Deeds Books). Sample size $(n)$ refers to the number of witness trees recorded. The top five taxa by frequency in each survey are in bold.

majority of forest was restricted to Wachusett Mountain (325 ha), Pine Hill to the east (19 ha), and Little Wachusett Hill to the south (21 ha; Massachusetts 1830). The slopes of Wachusett Mountain below $450 \mathrm{~m}$ a.s.1. were cleared grazing lands bordered by stone walls and fences (Cogbill 1995, Sinclair 1996; Fig. 2).

\section{Modern composition and structure}

The four old-growth areas are located on slopes $>20 \%$ between 425 and $520 \mathrm{~m}$ a.s.1., but differ substantially in aspect, forest structure, and composition (Table 2). The Old Indian area, located on a northfacing slope, includes a nearly equitable overstory importance value distribution of Fagus, Q. rubra, several Acer species, and Betula alleghaniensis (yellow birch; Table 2). Many tree crowns in this forest are stunted and gnarled, with an average height of $\sim 16 \mathrm{~m}$. The sapling layer of trees and shrubs includes $A$. pensylvanicum (striped maple) and A. spicatum (mountain maple) with lesser amounts of Hamamelis virginiana (witch hazel) and Fagus (Table 3). The Eastern and Southern Talus areas contain abundant $B$. alleghaniensis, $Q$. rubra, and Acer rubrum (red maple) in the overstory (Table 2). These steep, boulder-strewn sites also support short-statured (16-20 m tall), tattered trees with corresponding low overstory basal areas (17-27 $\mathrm{m}^{2} / \mathrm{ha}$ ) and multiple-stemmed sapling thickets of $A$. pensylvanicum, A. spicatum, $H$. virginiana, and $B$. alleghaniensis (Table 3). Many of the tree boles and branches in these areas show evidence of browsing by porcupine. Quercus saplings are absent or found in low densities at each of the three hardwood-dominated stands. Shade-tolerant Tsuga and scattered hardwoods dominate the overstory of the Hemlock old-growth area, contribute to a relatively high basal area $>60 \mathrm{~m}^{2} /$ ha, cast dense shade, and preclude development of a sapling layer (Table 2). Average tree heights in this stand range from 19 to $23 \mathrm{~m}$, several meters taller than in the hardwood-dominated stands.

Most of the hardwood species display reverse-J size distributions characteristic of multi-aged forests (Fig. 3). Quercus rubra are the largest trees found in the three hardwood areas with several individuals $>70$ $\mathrm{cm} \mathrm{dbh}$ on the Old Indian and Eastern Talus sites. This species is confined to only the largest size classes on the Old Indian site but is found in all size classes on the Southern Talus site. Betula alleghaniensis is prevalent in all size classes $\leq 60 \mathrm{~cm}$ dbh on the Eastern Talus site, and is common as smaller diameter stems on the Southern Talus and larger sized stems on the Old Indian site. A mixture of Acer species dominates the smaller size classes of the hardwood forests, with A. rubrum and Acer pensylvanicum common in all three areas and Acer saccharum more prominent in the Old Indian area (Fig. 3, Table 2). In contrast, the Hemlock forest structure approximates a unimodal size distribution (Fig. 3), as Tsuga occurs across a limited diameter range of 11-60 $\mathrm{cm}$. Large diameter Q. rubra and Betula lenta (black birch) also occur in this stand.

\section{Disturbance dynamics}

The hardwood stands are uneven-aged forests (Fig. 4). The oldest trees in the Old Indian area are $Q$. rubra that range from 287 to $322 \mathrm{yr}$ (breast-height age). Low but continuous recruitment of Quercus occurred only from 1675 to 1715 and 1780 to the early 1800s. Modest recruitment peaks of $A$. rubrum, A. saccharum, and Fagus occurred during the early 1800s, 1820s, and 1880 s, and a peak consisting primarily of A. pensylvanicum occurred in the 1950 s.

The Eastern Talus site contains B. alleghaniensis ranging in age from 17 to $370 \mathrm{yr}$ of age with nearly continuous recruitment since the 1740s (Fig. 4). Low but steady recruitment of $Q$. rubra from 1775 until the early 1830 s was followed by only a few individuals over the ensuing $90 \mathrm{yr}$ and none since 1930. Peak recruitment of other tree species occurred on this talus site during the 1820 s and the 1960s. Acer recruitment did not occur until the early 1900 s.

The Southern Talus differed from the Eastern Talus with an earlier cohort of $Q$. rubra from the 1730 s, a period of relatively high $Q$. rubra recruitment from 

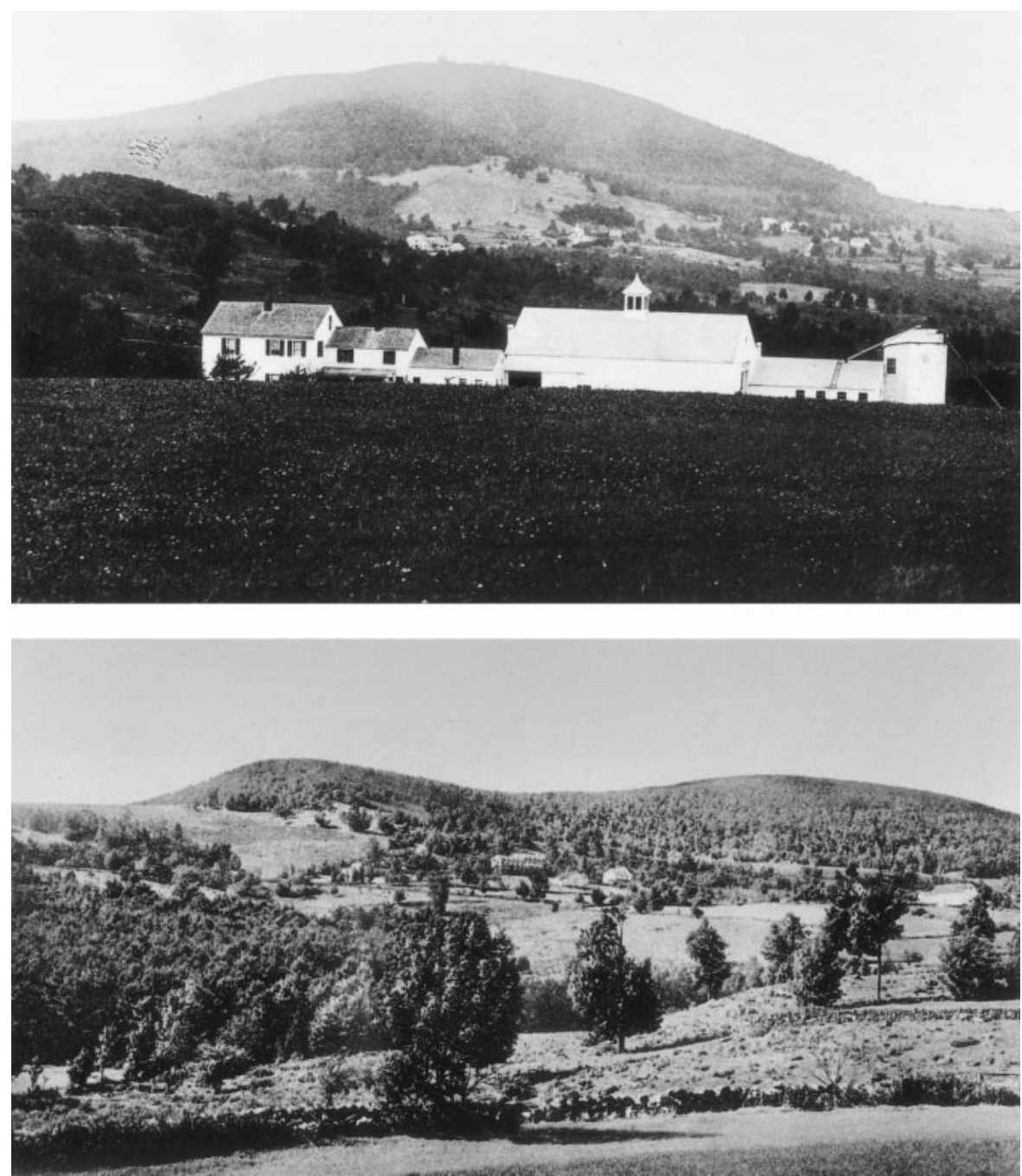

FIG. 2. Historical views of Wachusett Mountain, showing the upper slopes bordered by open pastures, in about the year 1900. The top panel is the view toward the southern flank of the mountain (showing a farmstead that was not a part of the Roper farm), while the bottom panel displays the southeastern and eastern slopes.

1770 to 1800 , sporadic recruitment throughout the 1800 s, and no Betula establishment until after 1830 . Later peaks in recruitment occurred during the 1840 s, 1940 s, and 1970s.

The Hemlock area differs considerably in developmental history from the hardwood stands as Tsuga, $Q$. rubra, and B. lenta recruited in low numbers from 1690 to 1770 and then nearly $70 \%$ of all overstory stems recruited in the ensuing $60-\mathrm{yr}$ period. By the late $1800 \mathrm{~s}$ recruitment diminished considerably and none of the sampled trees became established after 1893.

Radial growth analysis indicates that each oldgrowth area experienced a different disturbance history during the last three centuries (Fig. 5). Trees from the Old Indian area experienced major growth reductions, indicative of canopy damage, during the early and late $1700 \mathrm{~s}$, the early 1900s, and during the 1930s, 1950s, and 1970s. More than $20 \%$ of the sampled trees ex- perienced release immediately following reduction periods in the early 1900 s and in the 1940s. Trees from the Eastern Talus slope experienced significant crown damage during the late 1700s, 1830s, 1950s, and 1970s. Moderate release peaks occurred in the $1810 \mathrm{~s}$ and 1920 s, and a major release peak occurred in the early 1900s. Southern Talus trees indicate canopy damage occurred during the 1810s, 1900s, 1930s, 1950s, and 1970s. The peak release period occurred in the $1820 \mathrm{~s}$, although more modest release peaks were observed in the 1890s and 1940s. Trees from the Hemlock area did not experience any dramatic changes in ring width until modest reductions occurred during the 1830 s and 1840 s. Over $60 \%$ of the sampled trees experienced abrupt declines in the 1860 s and over $40 \%$ experienced declines in the early 1900 s. Periods of major and moderate release occurred from the 1920s through the 1940s and again in the 1970s. The only synchronous 
TABLE 2. Relative density (Dens.), basal area (BA), and importance values (IV) for trees of the given species $\geq 1.37 \mathrm{~m}$ tall and $\geq 8 \mathrm{~cm} \mathrm{dbh}$, and general stand characteristics within the four old-growth stands on Wachusett Mountain.

\begin{tabular}{|c|c|c|c|c|c|c|c|c|c|c|c|c|}
\hline \multirow[b]{2}{*}{ Species } & \multicolumn{3}{|c|}{ Old Indian } & \multicolumn{3}{|c|}{ Eastern Talus } & \multicolumn{3}{|c|}{ Southern Talus } & \multicolumn{3}{|c|}{ Hemlock } \\
\hline & Dens. & $\mathrm{BA}$ & IV $(\%)$ & Dens. & $\mathrm{BA}$ & IV (\%) & Dens. & $\mathrm{BA}$ & IV $(\%)$ & Dens. & $\mathrm{BA}$ & IV (\%) \\
\hline Acer pensylvanicum & 23.4 & 4.7 & 14.0 & 10.4 & 2.0 & 6.2 & 3.4 & 0.8 & 2.1 & $\ldots$ & $\ldots$ & $\ldots$ \\
\hline Acer rubrum & 16.0 & 15.6 & 15.8 & 20.8 & 11.7 & 16.3 & 29.7 & 14.4 & 22.0 & 5.1 & 4.1 & 4.6 \\
\hline Acer saccharum & 12.8 & 12.8 & 12.8 & 2.8 & 1.0 & 1.9 & 5.9 & 4.3 & 5.1 & $\ldots$ & $\cdots$ & $\cdots$ \\
\hline Acer spicatum & $\ldots$ & $\ldots$ & $\ldots$ & $\cdots$ & $\ldots$ & $\cdots$ & 0.9 & 0.1 & 0.5 & ... & $\ldots$ & $\cdots$ \\
\hline Betula alleghaniensis & 8.5 & 17.0 & 12.7 & 45.5 & 45.3 & 45.4 & 24.6 & 22.2 & 23.4 & 3.4 & 3.3 & 3.4 \\
\hline Betula lenta & $\cdots$ & $\cdots$ & $\ldots$ & $\cdots$ & $\cdots$ & $\ldots$ & $\cdots$ & $\cdots$ & $\cdots$ & 7.6 & 8.9 & 8.2 \\
\hline Carya glabra & $\ldots$ & $\ldots$ & $\ldots$ & $\cdots$ & $\cdots$ & $\ldots$ & 2.0 & 2.5 & 2.3 & $\cdots$ & $\ldots$ & $\cdots$ \\
\hline Carya ovata & $\ldots$ & $\cdots$ & ... & 1.3 & 0.9 & 1.1 & 1.2 & 0.9 & 1.0 & ... & $\ldots$ & $\ldots$ \\
\hline Castanea dentata & $\cdots$ & $\cdots$ & $\ldots$ & $\cdots$ & $\cdots$ & $\cdots$ & 0.9 & 0.2 & 0.5 & $\cdots$ & $\cdots$ & $\cdots$ \\
\hline Fagus grandifolia & 25.5 & 18.6 & 22.1 & $\cdots$ & $\cdots$ & $\cdots$ & 5.9 & 12.1 & 9.0 & $\cdots$ & $\cdots$ & $\cdots$ \\
\hline Fraxinus americana & $\ldots$ & $\ldots$ & $\ldots$ & 5.2 & 9.1 & 7.1 & 0.9 & 0.4 & 0.6 & $\ldots$ & $\ldots$ & $\ldots$ \\
\hline Hamamelis virginiana & 4.3 & 0.5 & 2.4 & $\ldots$ & $\ldots$ & $\cdots$ & $\cdots$ & $\cdots$ & $\ldots$ & $\ldots$ & $\ldots$ & $\ldots$ \\
\hline Ostrya virginiana & 2.1 & 0.5 & 1.3 & 3.9 & 0.8 & 2.4 & 6.8 & 1.3 & 4.0 & $\cdots$ & $\ldots$ & $\ldots$ \\
\hline Quercus rubra & 7.5 & 30.4 & 18.9 & 5.6 & 32.2 & 18.9 & 17.8 & 41.0 & 29.4 & 11.9 & 15.0 & 13.4 \\
\hline Sorbus americana & $\cdots$ & $\cdots$ & $\cdots$ & 6.5 & 2.0 & 4.2 & $\ldots$ & $\ldots$ & $\ldots$ & $\ldots$ & $\ldots$ & $\ldots$ \\
\hline Tsuga canadensis & $\cdots$ & $\cdots$ & $\cdots$ & $\cdots$ & $\cdots$ & $\cdots$ & $\cdots$ & $\cdots$ & $\cdots$ & 72.0 & 68.8 & 70.4 \\
\hline Total density (inds./ha) & \multicolumn{3}{|c|}{470} & \multirow{2}{*}{\multicolumn{3}{|c|}{$\begin{array}{l}385 \\
17.6\end{array}$}} & \multicolumn{3}{|c|}{590} & \multicolumn{3}{|c|}{590} \\
\hline Basal area $\left(\mathrm{m}^{2} / \mathrm{ha}\right)$ & \multicolumn{3}{|c|}{34.0} & & & & \multicolumn{3}{|c|}{27.3} & \multicolumn{3}{|c|}{61.2} \\
\hline Mean tree height $(\mathrm{m}) \dagger$ & \multicolumn{3}{|c|}{$16.3 \pm 0.4$} & \multicolumn{3}{|c|}{$\begin{array}{c}17.6 \\
18.3 \pm 1.4\end{array}$} & \multicolumn{3}{|c|}{$17.3 \pm 0.7$} & \multicolumn{3}{|c|}{$21.1 \pm 0.9$} \\
\hline Elevation (m a.s.1.) & \multicolumn{3}{|c|}{$488-533$} & \multicolumn{3}{|c|}{$\begin{array}{c}18.3 \pm 1.4 \\
430-465\end{array}$} & \multicolumn{3}{|c|}{$488-512$} & \multicolumn{3}{|c|}{$469-494$} \\
\hline Aspect & \multicolumn{3}{|c|}{$\mathrm{N}-\mathrm{NW}$} & \multicolumn{3}{|c|}{$\begin{array}{c}430-465 \\
E\end{array}$} & \multicolumn{3}{|c|}{$\mathrm{SE}-\mathrm{S}$} & \multicolumn{3}{|c|}{ W } \\
\hline Slope $(\%)$ & \multicolumn{3}{|c|}{$20-40$} & \multicolumn{3}{|c|}{$\begin{array}{c}E \\
35-40\end{array}$} & \multicolumn{3}{|c|}{$35-40$} & \multicolumn{3}{|c|}{$30-40$} \\
\hline
\end{tabular}

Note: Importance values were calculated by species as: (relative density + relative basal area)/2.

$\dagger$ Derived from four dominant and co-dominant trees in each stand. Values are means \pm 1 SE.

events detected in $\geq 20 \%$ of the trees among sites were periods of crown damage during the 1810s, 1900s, 1950s, and 1970s.

The volume of downed woody debris in all four areas ranged from 14 to $34 \mathrm{~m}^{3} / \mathrm{ha}$, with the Eastern Talus area containing the least and the Old Indian area containing the greatest amount (Table 4 ). In each case the majority of downed volume came from a few large $Q$. rubra or Tsuga and from uprooted trees rather than snapped individuals or branch fragments. Except for small-statured Acer trees, snag densities were low in all stands.

TABLE 3. Sapling $(>1.37 \mathrm{~m}$ tall and $<8 \mathrm{~cm}$ dbh) abundance (stems per hectare) within the four old-growth stands on Wachusett Mountain.

\begin{tabular}{lrrrr}
\hline \hline \multicolumn{1}{c}{ Species } & $\begin{array}{c}\text { Old } \\
\text { Indian }\end{array}$ & $\begin{array}{c}\text { Eastern } \\
\text { Talus }\end{array}$ & $\begin{array}{c}\text { Southern } \\
\text { Talus }\end{array}$ & $\begin{array}{c}\text { Hem- } \\
\text { lock }\end{array}$ \\
\hline Acer pensylvanicum & 580 & 485 & 550 & 20 \\
Acer rubrum & 60 & 15 & 105 & $\ldots$ \\
Acer saccharum & 45 & 25 & 45 & $\ldots$ \\
Acer spicatum & 455 & 615 & 190 & $\ldots$ \\
Betula alleghaniensis & 30 & 360 & 210 & $\ldots$ \\
Cornus alternifolia & 15 & $\ldots$ & $\ldots$ & $\ldots$ \\
Fagus grandifolia & 290 & $\ldots$ & 110 & $\ldots$ \\
Hamamelis virginiana & 325 & 200 & 890 & $\ldots$ \\
Ostrya virginiana & 5 & 5 & 55 & $\ldots$ \\
Prunus virginiana & $\ldots$ & 130 & $\ldots$ & $\ldots$ \\
Quercus rubra & $\ldots$ & 10 & 25 & $\ldots$ \\
Sambucus racemosa & $\ldots$ & 55 & $\ldots$ & $\ldots$ \\
Sorbus americana & 10 & 75 & 5 & $\ldots$ \\
Tilia americana & $\ldots$ & 15 & $\ldots$ & $\ldots$ \\
Tsuga canadensis & $\ldots$ & $\ldots$ & $\ldots$ & 50 \\
$\quad$ Total & 1815 & 1990 & 2185 & 70 \\
\hline
\end{tabular}

The orientation of downed stems differed by site and was preferentially downslope (Fig. 6).

\section{DiscusSION}

The structure, composition, and historical development of the recently discovered old-growth forests on Wachusett Mountain have exhibited highly variable spatial and temporal patterns over the last $300 \mathrm{yr}$. In order to assess shifts in recruitment dynamics from presettlement times to the present and place these results within a regional context, we begin with a comparison between witness-tree records from the area surrounding WMSR and the current age structure and composition of old-growth forests on the mountain. We then compare the stand dynamics and disturbance histories of four distinct areas that are located at the same elevation but differ in composition, aspect, and exposure. We close with an examination of the processes that have been important in contributing to the structure, appearance, and longevity of these forests, and how these unique and highly variable characteristics serve to broaden the current definitions of old-growth forests in the eastern U.S.

Regional presettlement forest composition in central Massachusetts consisted of Pinus, Tsuga, Fagus, and Acer in the central uplands and a higher abundance of Quercus and Carya in southern and broad lowland areas, where the growing season is longer and fires were apparently more frequent (Bromley 1935, Foster et al. 1998, Fuller et al. 1998). Witness-tree records from the Wachusett area correspond well with these patterns, 

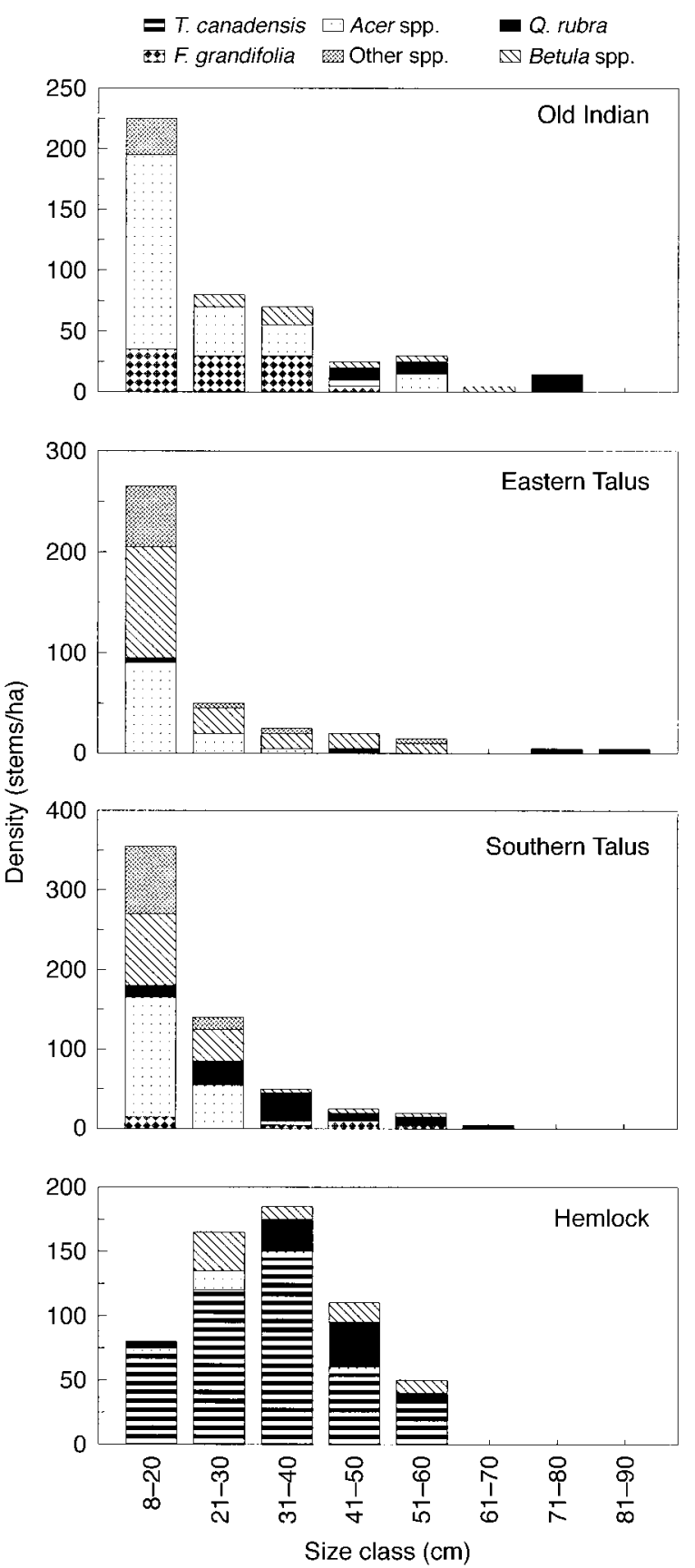

FIG. 3. Breast-height $(1.37 \mathrm{~m})$ diameter distribution of tree species within the four old-growth areas on Wachusett Mountain. Data for Acer and Betula species were combined.

with the low-elevation forests dominated by Quercus and Castanea. In broad, compositional terms, although certainly not in structure, the old-growth forests examined in this study are representative of the Massachusetts presettlement landscape. Historical records and current age-structure data suggest that Quercus rubra and northern hardwood species dominated presettlement forests on upper elevation slopes of WMSR.
Consequently, with the exception of the elimination of Castanea, it appears that present-day forests on upper and lower slopes of the mountain include the same species as in presettlement times.

Tree establishment dates indicate that recruitment of Q. rubra was abundant from the late 1600 s through 1830 in the Old Indian and Hemlock areas and declined dramatically thereafter. Quercus recruitment continued on the more open, talus sites, although these sites also experienced a later transition in recruitment towards Acer and Betula during the 20th century. The cessation of Quercus recruitment in the 20th century has been observed in many eastern old-growth and secondgrowth stands (Parker et al. 1985, Shotola et al. 1992, Mikan et al. 1994, Abrams et al. 1995, 1997, Roovers and Shifley 1997) and has been attributed in part to a decrease in fire frequency, which allowed mesic, shadetolerant species to proliferate (Abrams 1992). Indeed, there have been no sizable fires reported at the WMSR in the last $150 \mathrm{yr}$ and Fagus, Betula, and Acer species increased dramatically following the period of Quercus establishment. Soil charcoal, indicative of earlier, undated fires, was observed throughout the two non-talus stands and the age structure and growth chronologies from all stands are indicative of pulse-like episodes of establishment after disturbance. Therefore a change in disturbance regime involving a decline in fire over the historical period is consistent with the shift from oak recruitment to more shade-tolerant species recently.

Fire rotation intervals from 230 to $1500 \mathrm{yr}$ have been reported for hardwood forests in northern New England (Fahey and Reiners 1981). In southern New England, it is believed that presettlement fires were more frequent and intense in broad lowland areas (Fuller et al. 1998) and occurred only infrequently at high-elevation sites (Bromley 1935). In addition, fire frequency and intensity decreased northward and with elevation from coastal and lowland sites, broadly reflecting the pattern of climate, substrate, and Native American settlements in the region (Patterson and Sassaman 1988). It is unclear to what extent the native Nipmuck Indians shaped forest structure, land-use patterns, or fire regimes on WMSR, although the close proximity of their former village (within $1 \mathrm{~km}$ ) indicates the potential for fire activity.

Radial growth patterns of the oldest Quercus on all sites contained very few major, sustained release events and typically exhibited negative exponential growth trends of moderate to high growth rates for the first 50-100 yr, followed by persistent, slow growth over the last $200 \mathrm{yr}$ (D. A. Orwig, unpublished data). In addition, even-aged cohorts of shade-intolerant Quercus dating from the late 1600 s and early 1700 s suggest that the stands became established following disturbance that generated large canopy openings. This body of evidence strongly implies that fire had a profound impact in these forests during presettlement times. Several old-growth stands in the eastern U.S. have devel- 

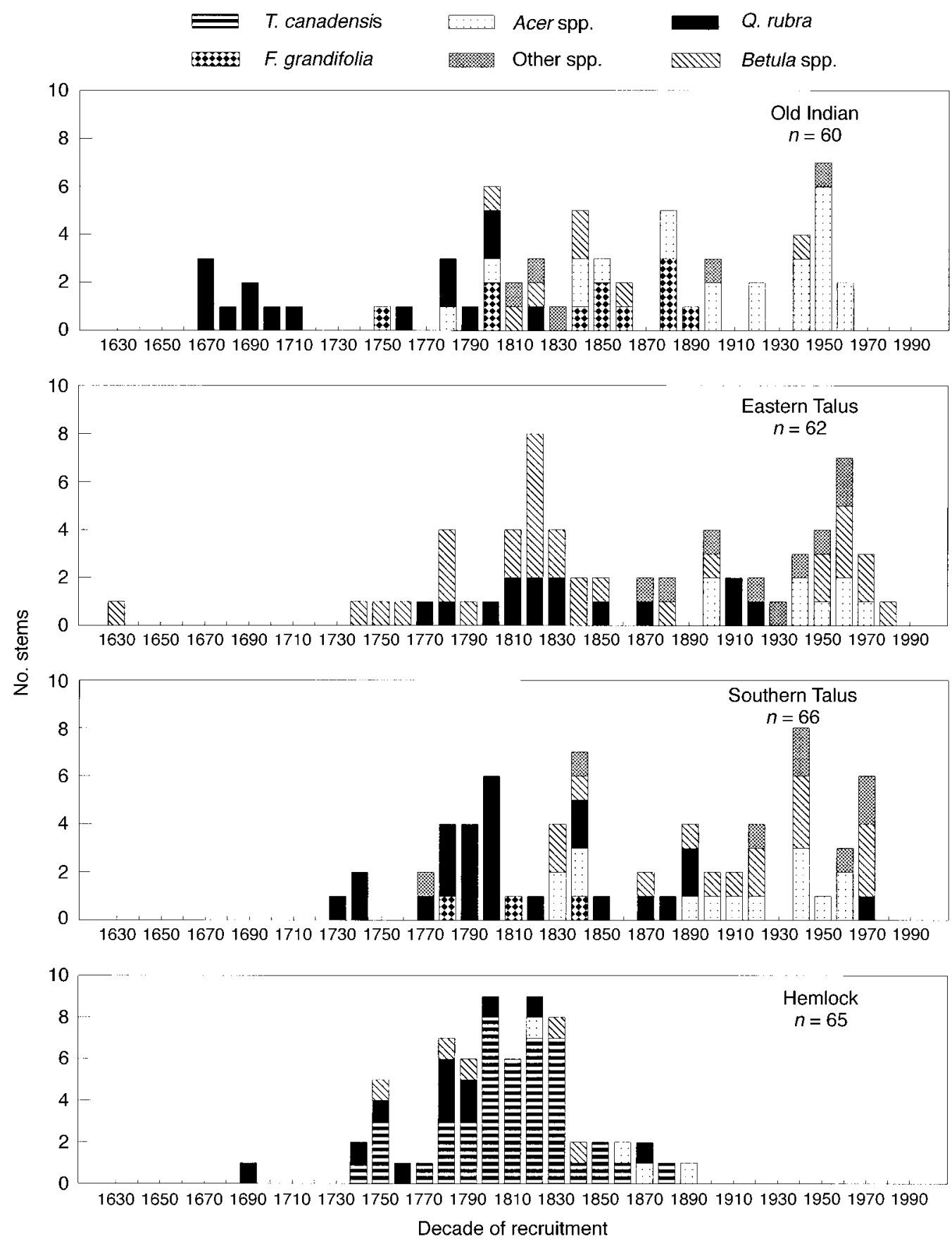

FIG. 4. Breast-height $(1.37 \mathrm{~m})$ recruitment dates by decade of major tree species sampled in the four old-growth areas on Wachusett Mountain. Data for Acer and Betula species were combined

oped following similar circumstances (Hough and Forbes 1943, Henry and Swan 1974, Boerner and Cho 1987, Foster 1988, Abrams and Orwig 1996). It is interesting to note that canopy damage resulting from frequent ice storms and the two most severe hurricanes in central New England since 1635 (i.e., 1815 and 1938), which both had severe impacts in the Wachusett region (Boose et al. 2001), led to establishment of other species but not Quercus. This suggests that advance regeneration of more shade tolerant species was established in the understory of these oak-dominated stands prior to the storms and then increased dramatically afterwards.

Despite the close proximity of the stands, the patterns of breast-height recruitment (recruitment to 1.37$\mathrm{m}$ height) in these forests following the initial Quercus 

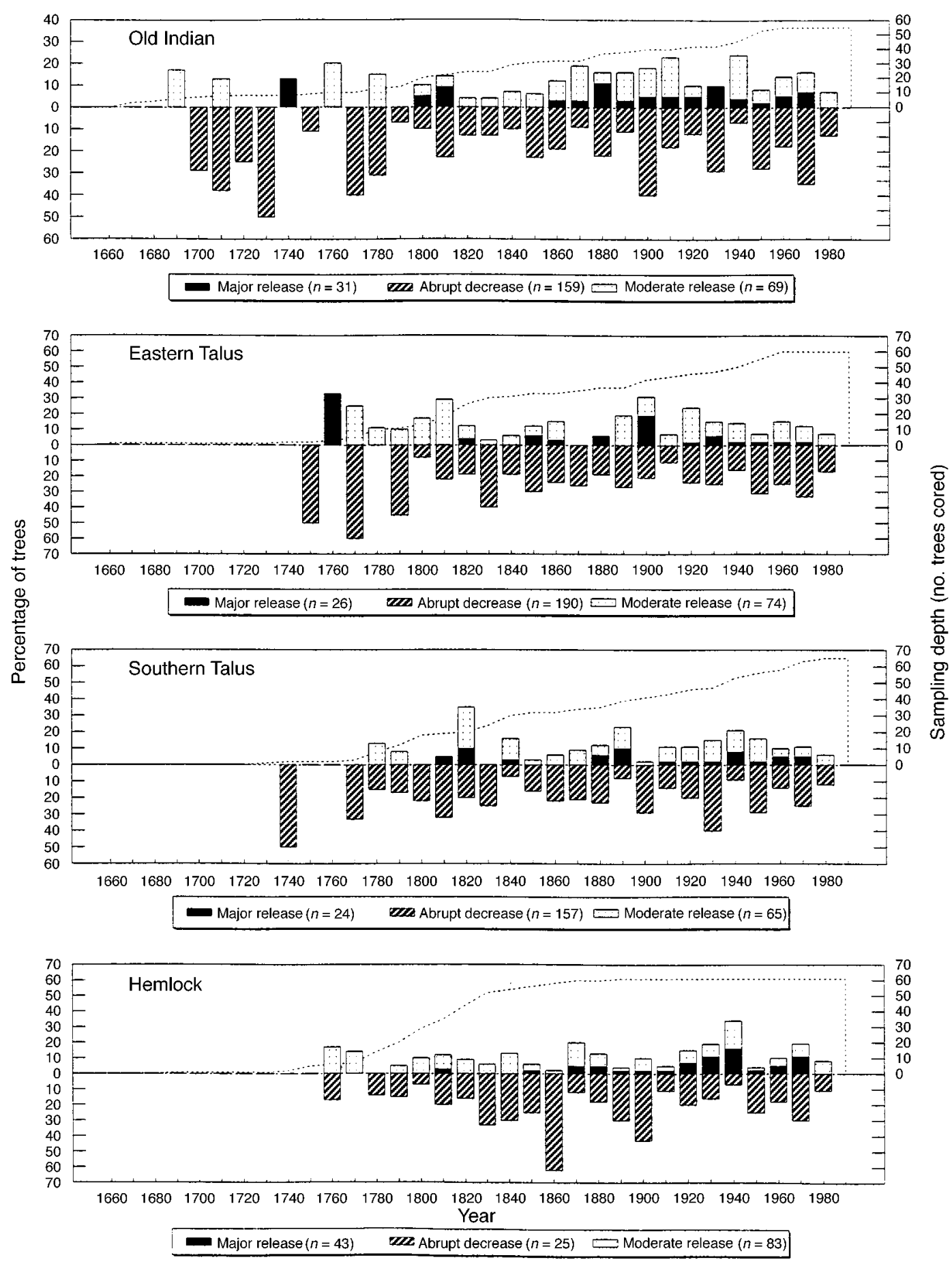

FIG. 5. Decadal distribution of dramatic releases (criteria from Lorimer and Frelich [1989]) and abrupt decreases ( $>25 \%$ growth declines sustained for 10 consecutive years) measured in tree cores from the four old-growth stands on Wachusett Mountain. Dashed lines represent the sampling depth (thoroughness) at each site. Sample size ( $n$ ) refers to the number of abrupt, major, or moderate changes in ring width.

dominance indicate that each area has developed differently over time. Abundant recruitment of several different species occurred in the hardwood areas and episodic recruitment began in the Hemlock area during the 1780s, suggesting widespread disturbance events, favorable climatic conditions for establishment, or both. The oldest trees, although few in number, experienced crown damage immediately preceding the 1780 s. The lack of synchronous peaks in recruitment since 1800 may indicate a shift to more localized dis- 
TABLE 4. Coarse woody debris volume $\left(\mathrm{m}^{3} / \mathrm{ha}\right)$, origin, and snag density in the four old-growth stands on Wachusett Mountain.

\begin{tabular}{lcccc}
\hline \hline \multicolumn{1}{c}{ Category } & $\begin{array}{c}\text { Old } \\
\text { Indian }\end{array}$ & $\begin{array}{c}\text { Eastern } \\
\text { Talus }\end{array}$ & $\begin{array}{c}\text { Tauthern } \\
\text { Talus }\end{array}$ & $\begin{array}{c}\text { Hem- } \\
\text { lock }\end{array}$ \\
\hline Species & & & & \\
Acer pensylvanicum & 2.6 & 0.5 & 0.4 & $\ldots$ \\
Acer rubrum & 2.8 & 0.2 & 0.1 & 0.7 \\
Acer saccharum & 0.4 & $\ldots$ & $\ldots$ & $\ldots$ \\
Acer unknown & $\ldots$ & $\ldots$ & 2.0 & $\ldots$ \\
Betula alleghaniensis & 5.6 & 6.0 & 4.0 & 0.5 \\
Betula lenta & $\ldots$ & $\ldots$ & $\ldots$ & 7.0 \\
Carya spp. & $\ldots$ & $\ldots$ & 1.5 & 0.1 \\
Castanea dentata & $\ldots$ & $\ldots$ & 2.1 & $\ldots$ \\
Fagus grandifolia & 11.4 & $\ldots$ & 0.1 & $\ldots$ \\
Hamamelis virginiana & 0.1 & $\ldots$ & $\ldots$ & $\ldots$ \\
Quercus rubra & 11.1 & $\ldots$ & 9.5 & 13.3 \\
Tsuga canadensis & $\ldots$ & 7.8 & $\ldots$ & 10.6 \\
Ostrya virginiana & $\ldots$ & $\ldots$ & 0.2 & $\ldots$ \\
Unknown spp. & 0.2 & $\ldots$ & $\ldots$ & $\ldots$ \\
Total volume & 34.2 & 14.5 & 19.9 & 32.2 \\
Origin of debris & & & & \\
Percentage stem snap & 18 & 23 & 12 & 10 \\
Percentage uprooted/ & 48 & 62 & 48 & 72 \\
$\quad$ base snap & & & & \\
Percentage unknown & 34 & 15 & 40 & 18 \\
Snags & & & & \\
Acer pensylvanicum & 80 & 15 & 10 & $\ldots$ \\
Acer rubrum & 20 & 25 & 35 & 15 \\
Betula alleghaniensis & 5 & 15 & 25 & $\ldots$ \\
Betula lenta & $\ldots$ & $\ldots$ & $\ldots$ & 5 \\
Fagus grandifolia & 10 & $\ldots$ & $\ldots$ & $\ldots$ \\
Quercus rubra & $\ldots$ & $\ldots$ & 15 & 15 \\
$\begin{array}{l}\text { Sorbus americana } \\
\text { Tsuga canadensis }\end{array}$ & $\ldots$ & 10 & $\ldots$ & $\ldots$ \\
Total snag density & 115 & 65 & 85 & 75 \\
$\quad$ (snags/ha) & & & & \\
\hline & & & & \\
\hline
\end{tabular}

turbances shaping dynamics or differential recovery rates among sites following severe disturbances. For example, after the 1815 hurricane, recruitment immediately followed growth releases in the Eastern Talus area, but occurred one to two decades later in the Old Indian and Southern Talus areas. Extensive ring-width reductions were observed in all four areas in the early 1900 s, a period that coincided with a severe ice storm on the mountain (WMSRC 1901). However, only limited recruitment ensued. Following the 1938 hurricane, the three hardwood stands experienced crown damage and release, but recruitment peaks occurred in different decades. Additional crown damage resulting from Hurricane Carol in 1954 may also be responsible for the observed recruitment patterns (Hitchcock 1971 $a, b$ ). In contrast, periods of frequent ring-width reductions (1860s and 1900s) and releases (1920s to the 1940s) recorded in the hemlock trees did not lead to any sampled recruitment. This suggests that frequent and occasionally widespread canopy damage was not intense enough to cause appreciable changes in understory conditions.

The technique of coupling release events with ringwidth reductions was useful in elucidating the history and severity of disturbance at these unusual sites. For example, a higher percentage of trees on the Southern Talus site appeared to have received crown damage (reduced ring widths) associated with the 1815 and 1938 hurricanes than release frequency alone suggested. The same is true of the damage associated with the 1900 ice storm, which was much more widespread than the associated ring-width increases. In addition, this methodology elucidated the chronic canopy disturbance depicted in study site descriptions.

Due to the lack of new recruits in the Hemlock area, there is a unimodal-shaped size distribution similar to those observed in several midwestern old-growth forests (Frelich and Lorimer 1985, Tyrrell and Crow 1994). Although heavy deer (Odocoileus virginianus) browse can prevent Tsuga establishment, the absence of Tsuga seedlings, saplings, and small trees in this study may be more indicative of a stem exclusion stage of forest development (Oliver 1980), in which the shade cast by the densely stocked overstory and associated root competition may preclude new establishment for extended periods of time (Hough and Forbes 1943, Hett and Loucks 1976, Lorimer 1995).

Despite the long history of recreation and increased visitation to the mountain over the last few decades, the old-growth areas have remained largely intact. Although the construction of summit buildings and barns beginning in 1870 implies selective firewood cutting or grazing in the area immediately below the summit at that time, there was no detectable impact on the forests we studied, which were located $\geq 500$ m downslope. Several lines of evidence, including documentary land-use records, lack of any visible stumps, age structure, composition, and tree ring dynamics of the four areas, suggest that these forests have not been cut in the past but have experienced frequent, localized disturbance over the last several hundred years.

The coarse woody debris provides further evidence of gap-phase dynamics, as the majority of downed woody volume was from a few large canopy trees, and with the exception of the Old Indian area, overall wind directions inferred from downed material across sites were not oriented in similar directions but rather with downhill aspect. This suggests that trees were not blown down by catastrophic wind events but rather blew down slope or perhaps fell down slope as a result of differential ice-loading on the asymmetrical crowns characteristic of most trees on upper slopes (Boerner et al. 1988; D. A. Orwig, personal observation). Wachusett Mountain snag densities are within the range reported for other northeastern old-growth sites, but the amount of CWD is considerably lower (Dunwiddie and Leverett 1996, Tyrell et al. 1998, McGee et al. 1999). The lower CWD values in our study may be partially explained by structural differences that exist in these forests relative to other sites. For example, basal area values from the talus sites (Table 4) are at or below the ranges $\left(25.7-43.3 \mathrm{~m}^{2} / \mathrm{ha}\right)$ summarized from many old-growth sites in the northeast (Tyrrell et 


\section{\begin{tabular}{c|c} 
Old Indian \\
$(n=33$ fallen trees $)$
\end{tabular} $343^{\circ}$ aspect}
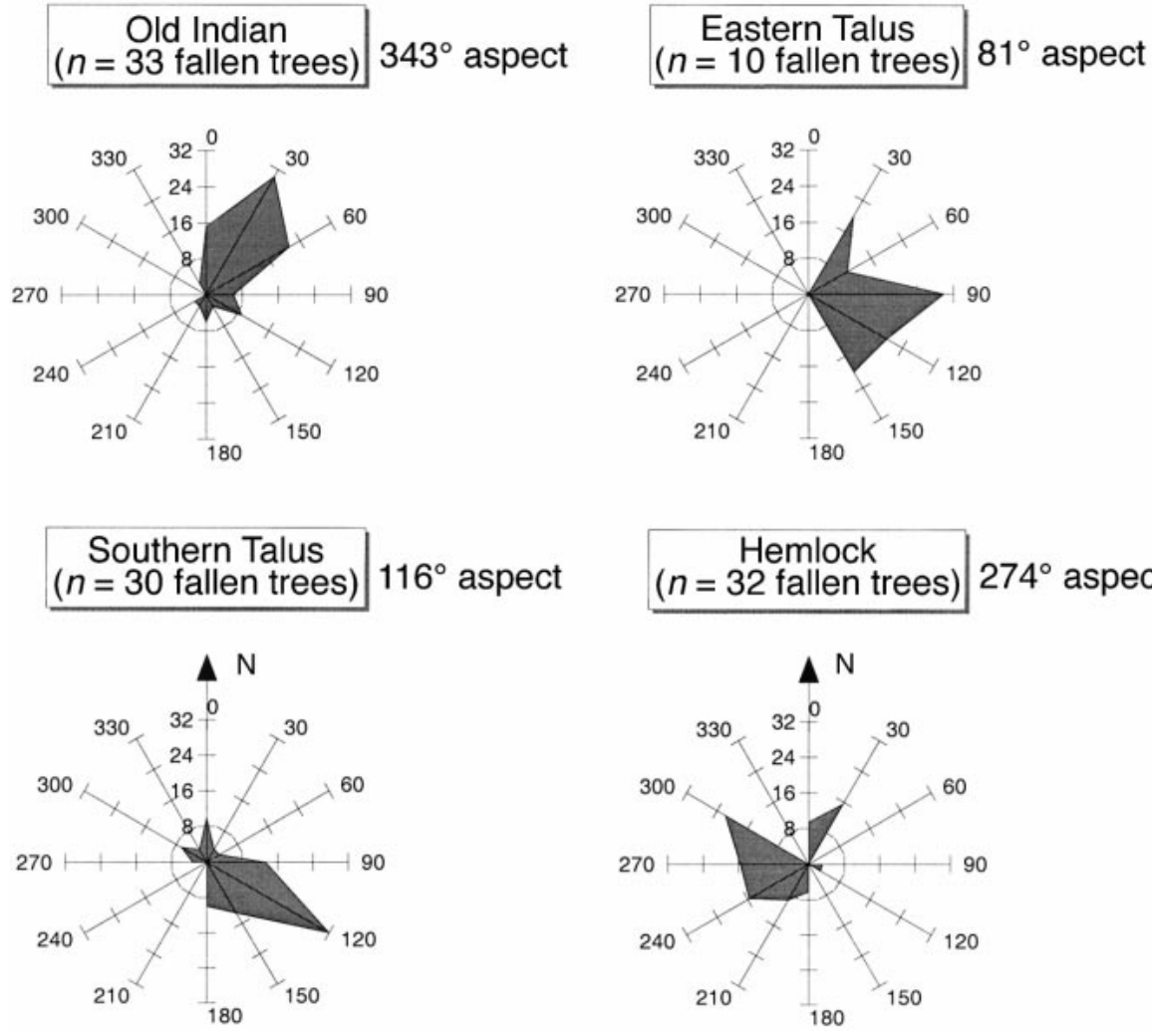
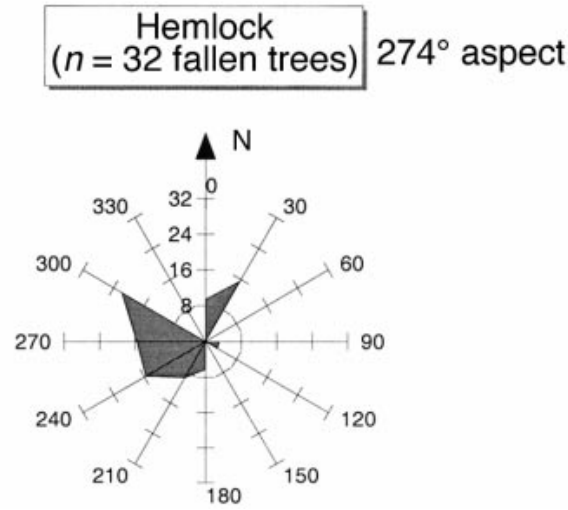

FIG. 6. Distribution of treefall direction (percentages by aspect) for the four old-growth areas on Wachusett Mountain. Sample sizes $(n=$ no. fallen trees in each area) are in parentheses.

al. 1998, McGee et al. 1999). In addition, average tree heights at the four Wachusett stands are 10-30 m lower than heights reported in other old-growth forests (Nichols 1913, Leopold et al. 1988, Abrams et al. 1995, Abrams and Orwig 1996, Dunwiddie and Leverett 1996, Dunwiddie et al. 1996).

Current forests on WMSR developed in response to several key factors. Geologic substrate, topographic position, edaphic properties, and climatic conditions have influenced upper elevation forests while anthropogenic clearance and other land-use activities have affected the forests at lower elevations. Various natural disturbances have also interacted with these factors, forming the basic structure and influencing the dynamics of these forests. Lower elevation sites experienced more intensive human alteration because the gentler slopes and deeper soils made them more suitable for agricultural activity. Structurally, present-day forests at lower elevations differ from older forests higher on the mountain. Young, smooth-barked trees, shade-intolerant species, and multiple-stemmed individuals are common below $450 \mathrm{~m}$ (Foster et al. 1997). Stone walls and barbed wire fences delimiting land and pasture boundaries are also common throughout much of the lower terrain (Cogbill 1995). With the exception of the leased ski area, most of the lower elevation areas have reverted from open agricultural land to forest within the last 70-100 yr, providing an intact, wooded buffer that surrounds the old-growth forest areas. This buffer maintains a continuous forest matrix of similar-sized or taller trees that is desirable for future forest protection (cf. Juday 1988).

The ice and wind stress that periodically damage or prune trees on the mountain (Fig. 7) may be effectively enhancing tree longevity by reducing the respiration load of tree crowns (Clark 1983) and/or by inducing physiological rejuvenation of stems and branches (Fortanier and Jonkers 1976, Del Tredici 1998). This mechanism reverses the effects associated with physiological aging by inducing growth of ontogenetically younger meristematic tissues, shortening internal distances of plant and nutrient transport, and increasing rootshoot ratios (Fortanier and Jonkers 1976, Del Tredici 1998). The short stature, compact canopy structure, and physical adaptation of roots and shoots to frequent wind stress make these stands relatively resistant to catastrophic hurricane winds that have historically occurred in the region (Everham and Brokaw 1996). Several individuals of $Q$. rubra, B. lenta, and B. alleghaniensis exceed or are very near the maximum longevity known for these species $(300,330$, and $385 \mathrm{yr}$, respectively; Nichols 1913, Morey 1936, Castro 1969). Of particular significance is the presence of $Q$. rubra exceeding 250-300 yr of age throughout the mountain, 
a
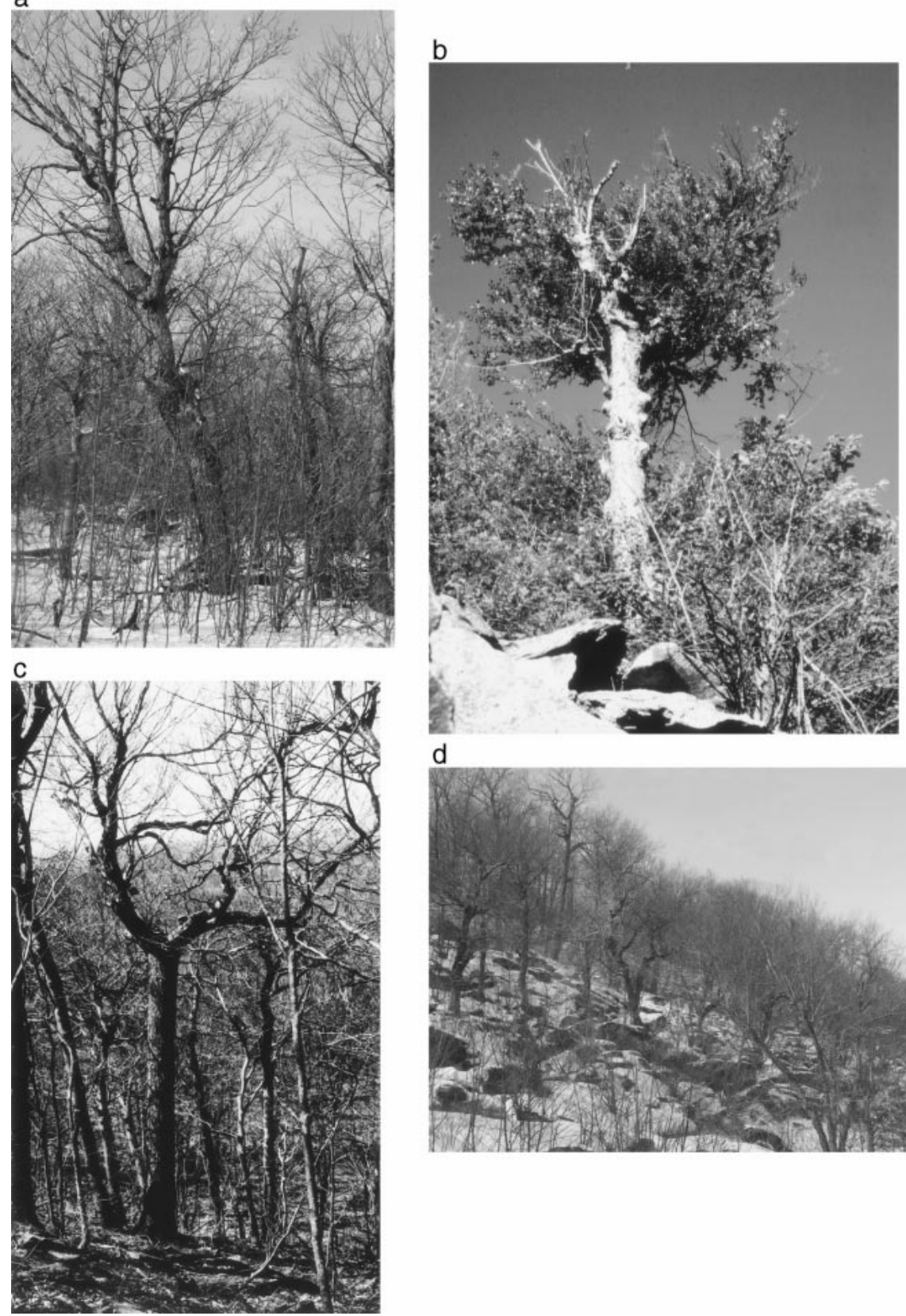

d

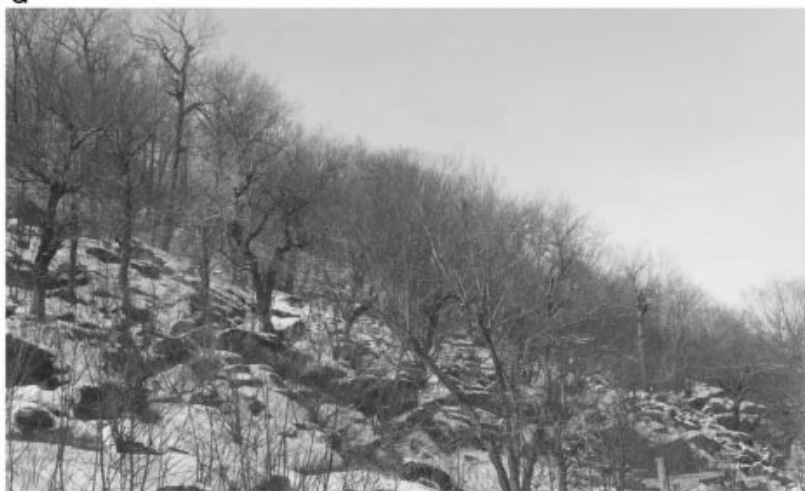

FIG. 7. Composite figure of site photos. (a) Leaning Quercus rubra on the upper Southern Talus site with few large upper branches. Note also the glaze located on the upper branch tips; (b) Open-grown Betula alleghaniensis located on the Eastern Talus site with stunted crown and multiple branch scars along the bole, indicative of pruning by wind, ice, and snow damage; (c) Sixty-five-centimeter dbh B. alleghaniensis with damaged crown in the Old Indian area; (d) Steep, open nature of Eastern Talus area with stunted $B$. alleghaniensis and $Q$. rubra trees.

perhaps as many as any site yet described from the eastern U.S. (Abrams et al. 1997).

The establishment of permanent plots in these areas will allow us to continue to assess dynamics over time in response to future disturbances, including climate change and potential pathogen attacks. This is particularly true for the hemlock stand, which currently is threatened by the rapidly advancing hemlock woolly adelgid (Adelges tsuage; Orwig and Foster 1998). Although no site can be considered free of anthropogenic influence, stands that have not been directly manipulated, like those studied at WMSR, provide information about natural disturbance regimes that can be used to help guide management and protection efforts. 


\section{CONCLUSIONS}

The forest structure and age classes of trees found in these four areas are uncommon and distinctive. All four areas contained trees $>250 \mathrm{yr}$ old and several species are approaching their known maximum longevities. Individual species abundance and recruitment dynamics exhibited highly variable spatial and temporal patterns among sites. The historical change in recruitment from Quercus to more shade-tolerant species, the asynchronous nature of ring-width decreases and releases, and the orientation of coarse woody debris suggest these stands have not experienced catastrophic disturbances that affected the entire mountain, but rather intense disturbances that included fire in the late 1600 s and early 1700s and more localized, gap-phase events over the last several centuries. The appearance and structure of these old-growth forests on steep, mountainous sites with harsh environments challenge romanticized expectations of old-growth forest structure. Forests on WMSR lack a vertically complex overstory with tall, statuesque trees and contain relatively low amounts of coarse woody debris and, with the exception of the $T$. canadensis stand, low overstory basal area. Due to a long history of ice, snow, and wind damage, as well as porcupine browse, the present-day appearance of these forests, containing widely spaced, stunted trees with gnarled canopies, closely resembles the earliest descriptions. These morphological characteristics may have contributed to their longevity by making them less desirable for cutting, less susceptible to catastrophic climatic events, and more likely to experience physiological rejuvenation. Ironically, it is these same traits that led people to ignore and thus unintentionally protect these forests, which now represent some of the largest remaining from the presettlement landscape of southern New England. Public sentiment regarding the value of these forests has changed dramatically since their discovery and ecological verification in 1995, and they are now considered worthy of immediate and rigorous protection (Massachusetts Department of Environmental Management, unpublished data). Recognition of the wide range of old-growth forest attributes that may exist on harsh sites, such as those found on Wachusett Mountain, may lead to future discoveries of ancient forests on other noncommercial land and a heightened awareness of the historical and ecological value of these forests.

\section{ACKNOWLEDGMENTS}

We would like to thank Chris Lawinksi, Dave Mausel, Matt Kizlinksi, and Steve Currie for assisting in field sampling and Kevin Dodds and Sarah Picard for tree core preparation and analysis. J. Burk, S. Clayden, R. Eberhardt, N. Enright, D. Francis, B. Hall, G. Motzkin, D. Parsons, and two anonymous reviewers provided helpful comments on earlier versions of this manuscript. B. Hall and B. Slater drafted Fig. 1. We appreciate the efforts of J. Donbrowo, B. Rivers, C. Pernaa, D. Stoddard, and T. Lavoie from the Massachusetts Department of Environmental Management who provided infor- mation and logistical assistance. This research was financially supported by the Massachusetts Department of Environmental Management, the A. W. Mellon Foundation, and the National Science Foundation LTER program (BSR 88/9411764).

\section{Literature Cited}

Abrams, M. D. 1992. Fire and the development of oak forests. BioScience 42:346-353.

Abrams, M. D., and D. A. Orwig. 1996. A 300-year history of disturbance and canopy recruitment for co-occurring white pine and hemlock on the Allegheny Plateau, U.S.A. Journal of Ecology 84:353-363.

Abrams, M. D., D. A. Orwig, and T. E. DeMeo. 1995. Dendroecological analysis of successional dynamics for a presettlement-origin white pine-mixed oak forest in the southern Appalachians, U.S.A. Journal of Ecology 83:123-133.

Abrams, M. D., D. A. Orwig, and M. J. Dockry. 1997. Dendroecology and successional status of two contrasting oldgrowth oak forests in the Blue Ridge Mountains, U.S.A. Canadian Journal of Forest Research 27:994-1002.

Blake, F. E. 1915. History of the town of Princeton. Volume one. Princeton, Massachusetts, USA.

Boerner, R. E. J., and D. Cho. 1987. Structure and composition of Goll Woods, an old-growth remnant in Northwestern Ohio. Bulletin of the Torrey Botanical Club 114: 173-179.

Boerner, R. E. J., S. D. Runge, S. Cho, and J. Kooser. 1988. Localized ice storm damage in an Appalachian Plateau watershed. American Midland Naturalist 119:199-208.

Boose, E. R., K. E. Chamberlin, and D. R. Foster. 2001. Landscape and regional impacts of hurricanes in New England. Ecological Monographs, 71:27-48.

Bromley, S. W. 1935. The original forest types of southern New England. Ecological Monographs 5:61-89.

Castro, P. A. 1969. A quantitative study of the subalpine forest of Roan and Bald Mountains in the southern Appalachians. Thesis. East Tennessee State University, Johnson City, Tennessee, USA.

Clark, J. R. 1983. Age-related changes in trees. Journal of Arboriculture 9:201-205.

Cline, A. C., and S. H. Spurr. 1942. The virgin upland forest of central New England. A study of old growth stands in the Pisgah mountain section of southwestern New Hampshire. Harvard Forest Bulletin 21.

Cogbill, C. V. 1995. An assessment of the historical ecology of the forests on the northeast slope of Wachusett Mountain, Massachusetts. Report prepared by Vanasse Hangen Brustlin.

Davis, M. B. 1996. Eastern old-growth forests: prospects for rediscovery and recovery. Island Press, Washington, D.C., USA.

Del Tredici, P. 1998. Aging, rejuvenation, and propagation in trees. Combined Proceedings of International Plant Propagators Society 48:3-8.

Dunwiddie, P. W., D. R. Foster, D. J. Leopold, and R. T. Leverett. 1996. Old-growth forests of southern New England, New York, and Pennsylvania. Pages 126-143 in M. B. Davis, editor. Eastern old-growth forests: prospects for rediscovery and recovery. Island Press, Washington, D.C., USA.

Dunwiddie, P. W., and R. T. Leverett. 1996. Survey of oldgrowth forest in Massachusetts. Rhodora 98:419-444.

Everham, E. M., III, and N. V. L. Brokaw. 1996. Forest damage and recovery from catastrophic wind. Botanical Review 62:113-185.

Fahey, T. J., and W. A. Reiners. 1981. Fire in the forests of Maine and New Hampshire. Bulletin of the Torrey Botanical Club 108:362-373.

Fisher, R. T. 1933. New England forests: biological factors. 
New England's prospect. American Geographical Society Special Publication 16:213-223.

Fortanier, E. J., and J. Jonkers. 1976. Juvenility and maturity of plants as influenced by their ontogenetical and physiological aging. Acta Horticulturae 56:37-44.

Foster, D. R. 1988. Disturbance history, community organization and vegetation dynamics of the old-growth Pisgah Forest, south-western New Hampshire, U.S.A. Journal of Ecology 76:105-134.

Foster, D. R., G. Motzkin, and B. Slater. 1998. Land-use history as long-term broad-scale disturbance: regional forest dynamics in central New England. Ecosystems 1:96119.

Foster, D. R., D. A. Orwig, and J. S. McLachlan. 1996a. Ecological and conservation insights from reconstructive studies of temperate old-growth forests. Trends in Ecology and Evolution 11:419-424.

Foster, D. R., D. A. Orwig, and J. F. O'Keefe. 1996b. Final report on old-growth forests on Wachusett Mountain. Report to the Department of Environmental Management, Commonwealth of Massachusetts. Harvard Forest, Petersham, Massachusetts 01366 USA.

Foster, D. R., D. A. Orwig, and J. F. O'Keefe. 1997. Oldgrowth forest monitoring on Wachusett Mountain. Report to the Department of Environmental Management, Commonwealth of Massachusetts. Harvard Forest, P.O. Box 68, Petersham, Massachusetts 01366 USA.

Frelich, L. E., and C. G. Lorimer. 1985. Current and predicted long-term effects of deer browsing in hemlock forests in Michigan, USA. Biological Conservation 34:99-120.

Fuller, J. L., D. R. Foster, J. S. McLachlan, and N. Drake. 1998. Impact of human activity on regional forest composition and dynamics in central New England. Ecosystems 1:76-95.

Gleason, H. A., and A. Cronquist. 1991. Manual of vascular plants of northeastern United States and adjacent Canada. Second edition. New York Botanical Garden, Bronx, New York, USA.

Griffith, G. E., J. M. Omernik, S. M. Pierson, and C. W. Kiilsgaard. 1994. Massachusetts ecological regions project. Department of Environmental Protection, Commonwealth of Massachusetts, Publication 17587.

Hanaford, J. L. 1852. History of Princeton, civil and ecclesiastical. C. B. Webb, Worcester, Massachusetts, USA.

Henry, J. D., and J. M. A. Swan. 1974. Reconstructing forest history from live and dead plant material-an approach to the study of forest succession in southwest New Hampshire. Ecology 55:772-783.

Hett, J. M., and O. L. Loucks. 1976. Age structure models of balsam fir and eastern hemlock. Journal of Ecology 64 1029-1044.

Hitchcock, J. H. 1971a. Wachusett Mountain landmark from the past; challenge for the future. Part 1. Appalachia 36 $5-33$.

Hitchcock, J. H. 1971b. Wachusett Mountain landmark from the past; challenge for the future. Part 2. Appalachia 36 83-107.

Hough, A. F., and R. D. Forbes. 1943. The ecology and silvics of forests in the high plateaus of Pennsylvania. Ecological Monographs 13:299-320.

Juday, G. P. 1988. Old-growth forests and natural areas: an introduction. Natural Areas Journal 8:3-6.

Kingsley, E., and F. Knab. 1895. Picturesque Worcester. Part II. North. W. F. Adams, Springfield, Massachusetts, USA.

Leopold, D. J., C. Reschke, and D. S. Smith. 1988. Oldgrowth forests of Adirondack Park, New York. Natural Areas Journal 8:166-189.

Lorimer, C. G. 1995. Dynamics and structural characteristics of eastern hemlock stands. Pages 43-59 in G. Mroz and J. Martin, editors. Hemlock ecology and management, pro- ceedings of a regional conference on ecology and management of eastern hemlock. University of Wisconsin, Madison, Wisconsin, USA.

Lorimer, C. G., and L. E. Frelich. 1989. A methodology for estimating canopy disturbance, frequency, and intensity in dense temperate forests. Canadian Journal of Forest Research 19:651-663.

Lutz, H. J. 1930. The vegetation of Heart's Content, a virgin forest in northwest Pennsylvania. Ecology 11:1-29.

Massachusetts Archives. 1830. Forest maps of Princeton and Westminster. Massachusetts State Archives, Boston (Dorchester), Massachusetts, USA.

Massachusetts Department of Environmental Management. 1979. Wachusett Mountain State Reservation Management Plan Draft. Department of Environmental Management, Clinton, Massachusetts, USA, or Wachusett Mountain State Reservation, Princeton, Massachusetts, USA.

Massachusetts Department of Environmental Management. 1985. Wachusett Mountain State Reservation guidelines for operations and land stewardship. Department of Environmental Management, Clinton, Massachusetts, USA, or Wachusett Mountain State Reservation, Princeton, Massachusetts, USA.

Massachusetts Department of Environmental Management. 1999. Wachusett Mountain State Reservation Resource Management and Protection Plan, Public Review Draft. Department of Environmental Management, Clinton, Massachusetts, USA, or Wachusett Mountain State Reservation, Princeton, Massachusetts, USA.

McGee, G. G., D. J. Leopold, and R. D. Nyland. 1999. Structural characteristics of old-growth, maturing, and partially cut northern hardwood forests. Ecological Applications 9: 1316-1329.

Mikan, C. J., D. A. Orwig, and M. D. Abrams. 1994. Age structure and successional dynamics of presettlement-origin chestnut oak forest in the Pennsylvania Piedmont. Bulletin of the Torrey Botanical Club 121:13-23.

Morey, H. F. 1936. Age-size relationships of Hearts Content, a virgin forest in northeastern Pennsylvania. Ecology 17: 251-257.

Nichols, G. E. 1913. The vegetation of Connecticut. II. Virgin forests. Torreya 13:199-215.

Nowacki, G. J., and M. D. Abrams. 1997. Radial-growth averaging criteria for reconstructing disturbance histories from presettlement-origin oaks. Ecological Monographs 67:225-249.

O'Keefe, J. F., and D. R. Foster. 1998. An ecological history of Massachusetts Forests. Pages 19-66 in C. H. W. Foster, editor. Stepping back to look forward. Harvard University Press, Cambridge, Massachusetts, USA.

Oliver, C. D. 1980. Forest development in North America following major disturbances. Forest Ecology and Management 3:153-168.

Orwig, D. A., and D. R. Foster. 1998. Forest response to the introduced hemlock woolly adelgid in southern New England, USA. Journal of the Torrey Botanical Society 125: 60-73.

Parker, G. R., D. J. Leopold, and J. K. Eichenberger. 1985. Tree dynamics in an old-growth, deciduous forest. Forest Ecology and Management 11:31-57.

Patterson, W. A., and K. E. Sassaman. 1988. Indian fires in the prehistory of New England. Pages 107-135 in G. P. Nicholas, editor. Holocene human ecology in northeastern North America. Plenum, New York, New York, USA.

Robinson, P., and R. D. Tucker. 1992. A traverse across the "wild unknown" of north-central Massachusetts from the Bronson Hill anticlinorum to the Fitchburg Pluton. Pages 424-445 in Guide book for the field trip for the 84th annual meeting of the New England Intercollegiate Geological Conference, Amherst, Massachusetts, USA. 
Roovers, L. M., and S. R. Shifley. 1997. Composition and dynamics of Spitler Woods, an old-growth remnant forest in Illinois (USA). Natural Areas Journal 17:219-232.

Shotola, S. J., G. T. Weaver, P. A. Robertson, and W. C. Ashby. 1992. Sugar maple invasion of an old-growth oak-hickory forest in southwestern Illinois. American Midland Naturalist 127:125-138.

Sinclair, W. M. 1996. Wachusett-Wajuset gatherings from then and when. Higginson Book, Salem, Massachusetts, USA.

Thoreau, H. D. 1843. A walk to Wachusett (July 1842). The Boston miscellany. Pages 25-46 in Thoreau in the mountains. 1982. Farrar, Straus, and Giroux, New York, New York, USA.

Thoreau, H. D. 1854. The journal of Henry David Thoreau (October 1854). Republished in B. Torrey and F. H. Allen, editors. 1962. Dover, New York, New York, USA.

Tyrrell, L. E., and T. R. Crow. 1994. Structural characteristics of old-growth hemlock-hardwood forests in relation to age. Ecology 75:370-386.

Tyrrell, L. E., G. J. Nowacki, T. R. Crow, D. S. Buckley, E.
A. Nauertz, J. N. Niese, J. L. Rollinger, and J. C. Zasada 1998. Information about old growth for selected forest type groups in the eastern United States. General Technical Report NC-197. U.S. Forest Service, North Central Forest Experiment Station, St. Paul, Minnesota, USA.

USDA. 1996. Interim soil report for northwest Worcester County, Massachusetts. Northwest Worcester Conservation District, in cooperation with U.S. Department of Agriculture Natural Resources Conservation Service, Holden, Massachusetts, USA.

WMSRC (Wachusett Mountain State Reservation Commission). 1901. First annual report of the Wachusett Mountain Commission. Wright and Potter Printing, Boston, Massachusetts, USA.

Westveld, M. V., and Committee on Silviculture, New England Section, Society of American Foresters. 1956. Natural forest vegetation zones of New England. Journal of Forestry 54:332-338.

Whitney, G. G. 1994. From coastal wilderness to fruited plain. Cambridge University Press, Cambridge, UK.

Whitney, P. 1793. The history of Worcester County. Isaiah Thomas, Worcester, Massachusetts, USA. 